\title{
AGENDA KEBIJAKAN PUBLIK PADA BADAN PERPUSTAKAAN DAN ARSIP (BPA) KOTA PEKANBARU
}

\author{
Hernimawati, Surya Dailiti dan Sudaryanto \\ Fakultas Ilmu Administrasi Universitas Lancang Kuning \\ e-mail: hernimawati@unilak.ac.id
}

\begin{abstract}
In Pekanbaru City Administration there are 43 Regional Devices Work Unit (SKPD), one of the Library and Archive Board (BPA) Pekanbaru City. BPA Has a big agenda in accordance with the vision of "Realization of Information Center and Documentation and Reading Center in Pekanbaru City". Based on pre-survey conducted there are problems that lack of public participation in utilizing the existence of BPA Pekanbaru City and the limited books / references required visitors. This public policy agenda can not be implemented entirely, whereas library and archival development is implemented with the aim of raising awareness, willingness of reading interest for every individual, public, institution and school. In order to realize the highest degree of community education systematically and sustainably as a mandate of the opening of the 1945 Constitution is to educate the life of the nation.The research was conducted at the Library and Archive Board (BPA) Pekanbaru City. Population and sample in this research is State Civil Apparatus that served in Library and Archives of Pekanbaru. The sampling technique used is simple random sampling (simple random). The number of civil servants 36 and daily personnel are 41 persons.From research activities conducted known that the Library and Archives (BPA) Pekanbaru comes as one of the seriousness of the Government of Pekanbaru City in the intellectual life of the nation. BPA Pekanbaru has the task to provide the best service in the field of library and filing. Website managed to be one source and delivery of information BPA Pekanbaru City. Then the BPA is good enough to implement the policies that have been made. From the questionnaires given to the employees, freelance and community personnel (pengaunjung) is known that as many as 17 respondents stated it was good public policy on the Library and Archives (BPA) Pekanbaru. Then as many as 3 respondents stated good enough and 0 for the less good.
\end{abstract}

Keywords: Agenda and Public Policy

Abstrak
Di Pemerintahan Kota Pekanbaru terdapat 43 Satuan Kerja Perangkat Daerah (SKPD), salah satunya Badan Perpustakaan Dan Arsip (BPA) Kota Pekanbaru.BPA Memiliki agenda besar sesuai dengan visi yakni “Terwujudnya Pusat Informasi dan Dokumentasi serta Pusat Baca di Kota Pekanbaru”. Berdasarkan pra survey yang dilakukan terdapat permasalahan yakni kurang partisipasi masyarakat dalam memanfaatkan keberadaan BPA Kota Pekanbaru dan terbatasnya buku-buku/ referensi yang dibutuhkan pengunjung.Agenda kebijakan publik ini tidak dapat dilaksanakan seluruhnya, padahal pembangunan perpustakaan dan kearsipan dilaksanakan dengan tujuan untuk meningkatkan kesadaran, kemauan minat baca bagi setiap individu, masyarakat umum, instansi dan sekolah.Agar terwujud derajat pendidikan masyarakat yang setinggi-tingginya secara sistematis dan berkesinambungan sebagai amanat dari pembukaan UUD 1945 yaitu mencerdaskan kehidupan bangsa.Penelitian dilakukan pada Badan Perpustakaan Dan Arsip (BPA) Kota Pekanbaru. Populasi dan sampel dalam penelitian ini adalah Aparatur Sipil Negara yang bertugas di Badan Perpustakaan Dan Arsip Kota Pekanbaru.Teknik penarikan sampel yang digunakan adalah simple random sampling (acak sederhana).Jumlah pegawai negeri sipil 36 dan tenaga harian lepas 41 orang. Dari kegiatan penelitian yang dilakukan diketahui bahwa Perpustakaan dan Arsip (BPA) Kota Pekanbaru hadir sebagai salah satu wujud keseriusan Pemerintah Kota Pekanbaru dalam mencerdaskan kehidupan bangsa.BPA Kota Pekanbaru mengemban tugas untuk memberikan pelayanan yang terbaik di bidang perpustakaan dan Kearsipan.Website yang dikelola menjadi salah satu sumber dan penyampaian informasi BPA Kota Pekanbaru.Kemudian BPA sudah cukup baik melaksanakan kebijakan yang tekah dibuat.Dari kuesioner yang diberikan kepada pegawai, tenaga harian lepas dan masyarakat (pengaunjung) diketahui bahwa 
sebanyak 17 responden menyatakan sudah baik agendak kebijakan publik pada Badan Perpustakaan Dan Arsip (BPA) Kota Pekanbaru.Kemudian sebanyak 3 responden menyatakan cukup baik dan 0 untuk yang kurang baik.

Kata Kunci : Agenda, Kebijakan Publik

\section{PENDAHULUAN}

Agenda adalah rencana yang akan dilakukan kedepan. Kebijakan publik secara sederhana adalah konsep dasar rencana pemerintah atau organisasi publik untuk mengatur kepentingan umum atau orang banyak.Sedangkan secara umum, pengertian kebijakan publik adalah segala sesuatu yang dikerjakan dan tidak dikerjakan oleh pemerintah untuk kepentingan umum.Segala sesuatu yang dimaksud adalah setiap aturan dalam kehidupan bersama, baik itu hubungan antarwarga maupun warga dengan pemerintah.

Kebijakan publik biasanya dituangkan dalam peraturan perundang-undangan seperti undang-undang (UU), peraturan presiden, dan peraturan daerah (perda) merupakan bentuk-bentuk kebijakan publik.Kebijakan publik atau kebijakan umum merupakan program-program yang diterapkan oleh pemerintah dalam arti luas untuk mencapai tujuan masyarakat. Dengan kata lain, kebijakan publik adalah suatu keputusan-keputusan dari lembaga yang berwenang atau pemerintah yang menyangkut kepentingan masyarakat luas. Seperti kebijakan tentang tarif dasar listrik (TDL), tarif telepon, harga BBM, dan tarif bus kota serta peningkatan peran perpustakaan.

Di Pemerintahan Kota Pekanbaru terdapat 43 Satuan Kerja Perangkat Daerah (SKPD), salah satunya Badan Perpustakaan Dan Arsip (BPA) Kota Pekanbaru.BPA Memiliki agenda besar sesuai dengan visi yakni "Terwujudnya Pusat Informasi dan Dokumentasi serta Pusat Baca di Kota Pekanbaru”. Berdasarkan pra survey yang dilakukan terdapat permasalahan yakni: Kurang partisipasi masyarakat dalam memanfaatkan keberadaan BPA Kota Pekanbaru, Terbatasnya buku-buku/ referensi yang dibutuhkan pengunjung.

Dari data lapangan diperoleh, agenda kebijakan publik pada BPA Kota Pekanbaru, sebagaimana. Dari data lapangan diperoleh, agenda kebijakan publik pada BPA Kota Pekanbaru. Agenda kebijakan publik ini tidak dapat dilaksanakan seluruhnya, padahal pembangunan perpustakaan dan kearsipan dilaksanakan dengan tujuan untuk meningkatkan kesadaran, kemauan minat baca bagi setiap individu, masyarakat umum, instansi dan sekolah.Agar terwujud derajat pendidikan masyarakat yang setinggitingginya secara sistematis dan berkesinambungan sebagai amanat dari pembukaan UUD 1945 yaitu mencerdaskan kehidupan bangsa.

\section{METODE}

\subsection{Lokasi Penelitian}

Penelitian dilakukan pada Badan Perpustakaan Dan Arsip (BPA) Kota Pekanbaru.

\subsection{Populasi dan Sampel}

Populasi dan sampel dalam penelitian ini adalah Aparatur Sipil Negara yang bertugas di Badan Perpustakaan Dan Arsip Kota Pekanbaru.Teknik penarikan sampel yang digunakan adalah simple random sampling (acak sederhana).Jumlah pegawai negeri sipil 36 dan tenaga harian lepas 41 orang.

\subsection{Sumber dan Jenis Data}

Sumber dan jenis data dalam penelitian ini adalah sebagai berikut: 


\section{Data Primer}

Data Primer adalah data yang kumpulkan langsung dari informan yang terpilih dalam penelitian ini. Dalam kegiatan penelitian kualitatif yang menjadi Aparatur pemerintah informasi adalah para informan (subjek) yang kompeten, mempunyai relevansi dengan setting sosial yang diteliti. Sedangkan tempat yang menjadi elemen dari situasi sosial adalah situasi dan kondisi lingkungan tempat yang berkaitan dengan permasalahan penelitian. (Iskandar, 2009:113). Penentuan Informan dalam penelitian ini, penulis merujuk pada kriteria yang disampaikan Spradley (dalam Iskandar:116) bahwa Informan sebagai Aparatur pemerintah data hendaknya memenuhi kriteria sebagai berikut :

a. Mereka yang menguasai atau memahami masalah yang diteliti.

b. Mereka yang sedang berkecimpung atau terlibat dalam kegiatan yang sedang diteliti.

c. Mereka yang mempunyai waktu yang memadai untuk diminta informasi.

d. Mereka yang tidak cendrung menyampaikan informasi hasil kemasan sendiri.

e. Mereka yang pada mulanya tergolong asing dengan peneliti sehingga menggairahkan untuk dijadikan semacam guru atau narasumber Aparatur pemerintah.

Berdasarkan kriteria di atas, maka yang menjadi key informan dalam penelitian ini adalah camat.

\section{Data Sekunder}

Data sekunder adalah data yang diperoleh dari literatur-literatur,media cetak, atupun media elektronik, dokumen administrasi, penelitian sebelum atau lainnya yang terkait.Teknik Pengumpulan Data

Untuk menghimpun data yang diperlukan, maka dipergunakan teknik pengumpulan data sebagai berikut:

Observasi

Peneliti mengobservasi atau melihat apa yang sedang berlangsung dilapangan, dalam hal ini peneliti mengunjungi lokasi atau melihat secara langsung proses keberlangsungan kegiatan perkantoran.

Wawancara

Wawancara adalah proses tanya-jawab dalam penelitian yang berlangsung secara lisan dalam mana dua orang atau lebih bertatap muka mendengarkan secara langsung informasi-informasi atau keteranganketerangan. (Narbuko, 2008: 83).

Kuestioner

Kuesioner adalah suatu daftar yang berisi pertanyaan-pertanyaan yang harus dijawab atau dikerjakan oleh responden yang ingin diselidiki (Bimo Walgito, 2010: 72). Angket ini digunakan untuk mengetahui tanggapan responden terhadap pertanyaan yang diajukan.

\subsection{Analisis Data}

Data yang telah terkumpul berdasarkan jenis dan bentuk data, untuk selanjutnya dianalisis secara deskriptif kualitatif.

\section{HASIL DAN PEMBAHASAN}

Penelitian tentang perpustakaan dan arsip dilakukan baik pada level lokal, nasional maupun internasional. Dari beberapa sumber diketahui bahwa untuk menciptakan hasil yang bagus dari sebuah institusi yang bernama perpustakaan dan rsip perlu dilakukan sebuah agenda, bahkan untuk hal yang kecil seperti penataan surat. Penataan surat masuk dan keluar dapat dilakukan dalam sebuah filling cabinet. Filling Cabinet adalah lemari arsip yang terdiri dari beberapa laci.

Konsep administrasi dapat diartikan sebagai suatu proses pengorganisasian tugas-tugas dan kegiatan dari berbagai tingkatan dan jenis pekerjaan secara sistematik dalam organisasi. Proses administrasi secara hierarki mengerjakan tiga fungsi utama, yaitu (1) fungsi pengarahan organisasi yang berkaitan dengan proses perencanaan jangka panjang, (2) fungsi manajemen organisasi yang berkaitan dengan upaya mempertahankan organisasi sebagai suatu pekerjaan yang terus berlangsung lama, seperti memberikan 
bahan, sarana, instruksi dan peciptaan iklim yang diperlukan oleh staf teknis atau professional yang terlibat dalam proses produksi, (3) fungsi pengawas, yaitu kontroling dan evaluasi atasan kepada bawahan dengan cermat, tegas dan dapat dipertangungjawabkan dengan baik dan benar, (Asep, 2012).

Sementara organisasi menurut Robbins dan Judge dalam Danang dan Burhanuddin (2011), adalah suatu unit social yang terdiri dari dua orang atau lebih, dikoordinasi secara sadar dan berfungsi dalam suatu dasar yang relative terus menerus unuk mencapai satu atau serangkaian tujuan. Agar organisasi dapat mencapai tujuannya secara efektif dan efisien maka dibutuhkan manajer.

Manager sebagai bagian dari sumber daya manusia. Pengertian manajemen sumber daya manusia menurut Byars dan Rue dalam Siti dan Tri (2013), adalah aktivitas yang mencakup pengadaan dan pengkoordinasian sumber daya manusia.Sedangkan pengertian sumber daya manusia menurut Jackson dan Schuler dalam Byars dan Rue (2013), adalah orang yang berbakat dan bersemangat tinggi yang tersedia bagi organisasi sebagai kontributor potensial untuk menciptakan dan merealisasikan tujuan, misi dan visi organisasi.

Oleh karena itu diperlukan perencanaan dalam menjalankan organisasi.Dalam ari luas, perencanaan merupakan upaya manusia meminimalkan ketidakpastian.Perencanaan yang ideal adalah langkah-langkah yang dilakukan manusia agar kepastian semakin dekat dalam kehidupan manusia. Perencanaan dalam ari sempit, sesungguhnya merupakan derivate dari kemampuan foresight iu, yaitu kemampuan mengukur (measuring). Ini perencanaan yang ideal sesungguhnya adalah mengukur, (Riant dan Randy, 2011).

Begitu pula dalam rangka pembangunan wilayah seperti kantor camat diperlukan perencanaan yang ideal. Sebab kantor camat memiliki banyak potensi yang harus dikembangkan salah satunya pariwisata. Dalam hal ini menurut Bambang (2013), keterkaitan sektor pariwisata terutama menyangkut aspek pemanfaatan sumber daya, dukungan sarana dan prasarana dan infrastruktur, dukungan SDM, dukungan kebijakan kemudahan perijinan, invetasi serta bentuk - bentuk regulasi lainnya.

Dalam hal ini tidak terlepas dari ilmu politik yang sudah setiap hari aktifitasnya kita saksikan diberbagai media baik cetak maupun elektronik.Menurut Padmo dan Nazaruddin (2009), ilmu politik merupakan bagian dari usaha manusia yang berkesinambungan untuk memahami dirinya.Setiap tindakan politik melibatkan beberapa nilai politik pokok yang mendasarinya. Adalah tepat bahwa renungan pokok para ilmuwan politik, sejak plato sampai awal abad kedua puluh, tertuju pada nilai-nilai yang dipandang sebagai penting bagi warga negara yang baik dan negara yang adil.

Selanjutnya, hal ini akan dipengaruhi dengan system politik yang berlaku di suatu negara. Seperti Indonesia dengan sisem politik demokrasi Pancasila, akan berbeda pelaksanaan sistem politiknya dengan negara lain, katakanlah Malaysia. Menurut Beddy (2012), system politik adalah suatu keseluruhan komponen-komponen atau lembaga-lembaga yang berfungsi dibidang politik yang kegiatannya menyangkut penentu kebijakan umum (public policies) dan bagaimana kebijakan itu dilaksanakan, yaitu hal-hal yang menyangkut kehidupan negara atau pemerintahan. Kemudian, berinteraksi berdasarkan proses-proses (proses saling pengaruh mempengaruhi) yang dapat diramalkan untuk memenuhi kebutuhan publik.

Di Indonesia semuanya harus mengacu kepada Pancasila dan UUD NRI 1945 agar tidak timbul hal yang negatif.Oleh karena itu Pacasila harus dipahami dari pendidikan dasar sampai perguruan tinggi.Kenapa? Karena dalam UU No 20 ahun 2003 tentang system pendidikan nasional dan juga termuat dalam SK Dirjen Dikti No 43/ Dikti/ Kep/ 2006, dijelaskan bahwa tujuan materi Pancasila dalam ramburambu Pendidikan Kepribadian mengarahkan pada moral yang diharapkan terwujud dalam kehidupan sehari-hari yaitu perilaku yang memancarkan iman dan taqwa terhadap Tuhan YME dalam masyarakat yang terdiri atas berbagai golongan agama, kebudayaan dan beraneka ragam kepentingan, Kaelan (2010).

Tapi semua harus paham dengan jati dirinya sebagai warga negara Indonesia.Sebab setelah seseorang memperoleh kewarganengaraan suatu negara otomatis orang tersebut menjadi warga Negara.Ia mempunyai hubungan hak dan kewajiban yang bersifat timbal balik terhadap negaranya. Di Indonesia 
hak warga Negara terhadap negaranya telah diatur dalam UUDN RI 1945, diantaranya hak azasi manusia, (Subhan dan Asep; 2011).

Bagi masyarakat Indonesia umumnya yang identic dengan Islam, begitu pula di Riau, seorang warga Negara harus menjaga diri agar berahlaq yang baik. Menurut Abu dan Noor (2008), ahlaq atau system perilaku ini terjadi melalui satu konsep atau seperangkat pengertian tentang apa dan bagaimana sebaiknya ahlaq itu harus terwujud. Konsep atau seperangkat pengertin tentang apa dan bagaimana sebaiknya ahlaq itu, disusun oleh manusia didalam system idenya. Sistem ide ini adalah hasil proses daripada kaidah-kaidah yang dihayati dan dirumuskan sebelumnya. Kaidah atau norma yang merupakan ketentuan ini timbul dari satu sisem nilai yang terdapat dalam Al quran dan Sunnah.

Disisi lain, manusia selanjutnya melakukan penelitian untuk menjawab berbagai persoalan. Penelitian (research) berasal dari kata Perancis (kuno) recerchier atau recherche yang berarti mencari atau menemukan.Menurut Shuttleworth dalam Muri (2014), research dalam arti luas dapat diartikan sebagai kegiatan pengumpulan data, informasi dan fakta untuk kemajuan pengetahuan.

Monitoring atau pengawasan merupakan kegiatan yang sangat penting untuk mengetahui kualitas, efektifitas, efisiensi, capaian dan dampak dari sebuah program kerja yang telah direncakan dan dilaksanakan. Conor dalam Agus dkk (2012), menjelaskan, bahwa keberhasilan dalam mencapai tujuan, separuhnya ditentukan oleh rencana yang telah ditetapkan dan setengahnya lagi fungsi oleh pengawasan atau monitoring.

Pihak yang melakukan pengawasan haruslah yang memiliki legalitas.Azas legalias merupakan salah satu prinsip utama yang dijadikan sebagai dasar dalam setiap penyelenggaraan pemerintahan dan kenegaraan di setiap Negara hokum terutama bagi Negara-negara hokum dalam system kontinental.Dengan demikian (Ridwan; 2010), substansi azas legalitas adalah wewenang, yakni; kemampuan untuk melakukan tindakan-tindakn hokum tertentu.

Menurut Deddy Mulyadi (2015), kunci utama memahami good governance dalam pandangan Masyarakat Transparansi Indonesia (MTI) adalah pemahaman atas prinsip - prinsip yang mendasarinya. Bertolak dari prinsip-prinsip ini didapat tolok ukur kinerja suatu pemerintah. Prinsip - prinsip tersebut kata Hardjasoemantri dalam Deddy Mulyadi (2015) meliputi:

1. Partisipasi Masyarakat, Semua warga masyarakat mempunyai suara dalam pengambilan keputusan, baik secara langsung maupun melalui lembaga perwakilan sah yang mewakili kepentingan mereka. Partisipasi menyeluruh dibangun berdasarkan kebebasan berkumpul dan mengungkapkan pendapat, serta kapasitas untuk berpartisipasi secara konstruktif.

2. Tegaknya Supremasi Hukum, Kerangka hukum harus adil dan diberlakukan tanpa pandang bulu, termasuk di dalamnya hukum-hukum yang menyangkut hak asasi manusia.

3. Transparansi, Tranparansi dibangun atas dasar arus informasi yang bebas. Seluruh proses pemerintahan, lembaga-lembaga dan informasi perlu dapat diakses oleh pihak-pihak yang berkepentingan, dan informasi yang tersedia harus memadai agar dapat dimengerti dan dipantau.

4. Peduli pada Stakeholder, Lembaga-lembaga dan seluruh proses pemerintahan harus berusaha melayani semua pihak yang berkepentingan.

5. Berorientasi pada Konsensus, Tata pemerintahan yang baik menjembatani kepentingankepentingan yang berbeda demi terbangunnya suatu konsensus menyeluruh dan yang terbaik bagi kelompok masyarakat, dan terutama dalam kebijakan dan prosedur.

6. Kesetaraan, Semua warga masyarakat mempunyai kesempatan memperbaiki atau mempertahankan kesejahteraan mereka.

7. Efektifitas dan Efisiensi, Proses-proses pemerintahan dan lembaga-lembaga membuahkan hasil sesuai kebutuhan warga masyarakat dan dengan menggunakan sumber-sumber daya yang ada seoptimal mungkin. 
8. Akuntabilitas, Para pengambil keputusan di pemerintah, sektor swasta dan organisasi-organisasi masyarakat bertanggung jawab baik kepada masyarakat maupun kepada lembaga-lembaga yang berkepentingan. Bentuk pertanggung jawaban tersebut tergantung dari jenis organisasi yang bersangkutan.

9. Visi Strategis, Para pemimpin dan masyarakat memiliki perspektif yang luas dan jauh ke depan atas tata pemerintahan yang baik dan pembangunan manusia, serta kepekaan untuk mewujudkannya, harus memiliki pemahaman atas kompleksitas kesejarahan, budaya dan sosial yang menjadi dasar bagi perspektif tersebut.

Selain prinsip-prinsip good governance yang perlu diperhatikan dalam pencapaian tujuan adalah agenda kebijakan dan partisipasi masyarakat. Menurut Abidin (2012), beberapa di antara faktor-faktor yang berpengaruh terhadap proses penyusunan agenda kebijakan publik adalah:

1. Perkembangan sistem pemerintahan yang demokratis

2. Sikap pemerintah dalam proses penyusunan agenda

3. Bentuk pemerintahan atau realisasi otonomi daerah

4. Partisipasi masyarakat.

Dari kegiatan penelitian yang dilakukan diketahui bahwa Perpustakaan dan Arsip (BPA) Kota Pekanbaru hadir sebagai salah satu wujud keseriusan Pemerintah Kota Pekanbaru dalam mencerdaskan kehidupan bangsa.BPA Kota Pekanbaru mengemban tugas untuk memberikan pelayanan yang terbaik di bidang perpustakaan dan Kearsipan. Website yang dikelola menjadi salah satu sumber dan penyampaian informasi BPA Kota Pekanbaru.Kemudian BPA sudah cukup baik melaksanakan kebijakan yang tekah dibuat.

Dari kuesioner yang diberikan kepada pegawai, tenaga harian lepas dan masyarakat (pengaunjung) diketahui bahwa sebanyak 17 responden menyatakan sudah baik agendak kebijakan publik pada Badan Perpustakaan Dan Arsip (BPA) Kota Pekanbaru.Kemudia sebanyak 3 responden menyatakan cukup baik dan 0 untuk yang kurang baik.

Dari kondisi tersebut bearti semua responden sama -sama mengakui bahwa BPA Kota Pekanbaru telah menjalankan agenda kebijakan publik yang ada di kantor tersebut. Hal ini juga diperkuat dari hasil wawancara dengan Kepala Sub Bagian Bina Program

"Masyarakat sudah ikut serta dalam mendukung agenda kebijakan publik yang ada di Kantor BPA Kota Pekanbaru.Salah satu langkah awalnya adalah dengan menjadi pengunjung, kemudian menjadi anggota.Selanjutnya memberikan masukan dalam berbagai agenda kebijakan publik yang dibuat, yakni dengan adanya kerjasama antar BPA Kota Pekanbaru dengn instansi lainnya.Selanjutnya ada perpustakaan instansi lain yang diberikan pembinaan oleh BPA Kota Pekanbaru. Seperti SMP Negeri 10, $R S$ pemerintah, penyediaan perpustakaan keliling. Ini semua merupakan hasil dari dukungan masyarakat terhadap agenda kebijakan publik BPA Kota Pekanbaru”.

Oleh karena itu, pada tanggapan respoden, kurang baik, tidak ada satupun respon yang memilihnya. Artinya masyaraka telah menjadi bahwa apa yang dilakukan oleh BPA Kota Pekanbaru sudah benar. Baik itu untuk agenda pengadaan bahan, pekerjaan, pelaksanaan kordinasi, pembuata file.Dari segi tempat Kantor BPA Kora Pekanbaru sudah berusaha dekat dengan rakat. Dengan demikian raktar/ pengunjung akan degan mudah menerima kebijakan penerintah baik langsung maupun tidak langsung.

Agenda kebijakan tidak lain adalah sebuah daftar permasalahan atau isu yang mendapat perhatian serius karena berbagai sebab untuk ditindaklanjuti atau diproses pihak yang berwenang menjadi kebijakan. Apakah kebijakan yang akan dibuat dapat memenuhi kepentingan semua pihak dalam masyarakat, terdapat berbagai kepentingan, kekuasaan, dan kecenderunganyang berbeda. Akibatnya, tidak semua kepentingan tertampung dalam agenda kebijakan. Penyaringan masuk dari berbagai isu dan kepentingan ke dalam kebijakan merupakan proses tersendiri yang tidak mudah. 


\section{Perkembangan Sistem Pemerintahan Yang Demokratis}

Setiap pemerintah mempunyai warna dan ciri tersendiri dalam kebijakan yang dibuatnya.Hal ini merupakan variasi yang menarik bagi para ilmuwan politik dan kebijakan publik. Kebijakan Soeharto misalnya, mempunyai gaya yang berbeda dengan kebijakan Soekarno, sekalipun kedua pemerintahan itu mempunyai bentuk yang sama sebagai otoritarian. Begitu juga antar gaya kebijakan Habibie dengan gaya kebijakan Gus Dur dan Megawati. Masing masing mempunyai gaya dan ciri tersendiri yang berbeda. Perbedaan itu tidak saja terletak pada sistem pemerintahan yang dianut, tetapi juga pada gaya kepeminpinan yang dipengaruhi pada latar belakang pendidikan, budaya, dan kepribadian masing-masing. Di samping itu, terdapat perbedaan lain yang oleh Huntington dikatakan sebagai degree of government, yaitu derajat yang menunjukan kemampuan pemerintah, sejauh mana kebijakan yang dibuatnya mampu diimplementasikan.

Jika ditelaah lebih lanjut, terlihat bahwa perbedaan antara kebijakan yang dibuat dengan kemampuan implementasi disebabkan oleh salah satu atau dua faktor, yaitu kelemahan konsepsi kebijakan itu sendiri dan kelemahan Administrasi atau birokrasi pemerintah sebagai sarana implementasi kebijakan. Kelemahan pertama sebagai akibat dari terpisahnya masyarakat dalam proses perumusan kebijakan publik.

\section{Sikap Pemerintah Dalam Proses Penyusunan Agenda}

Pertanyaan lebih lanjut adalah apa agenda kebijakan itu? bagaimana suatu isu masuk dalam agenda, dan bagaimana sikap pemerintah menhadapi proses penyusunan agenda itu? secara singkat, agenda kebijakan dapat disebutkan sebagai daftar permasalahan atau isu untuk ditindaklanjuti "a listing of items for action".

Sementara itu Edward dan Sharkausky menyebutnya sebagai permasalahan yang mendapat perhatian yang aktif dan serius dari para pengambil kebijakan yang penting "items receiving active and serios consideration by importand policy makers". Sebagai akibat dari persaingan tajam di antara berbagai kepentingan, hanya beberapa isu saja yang mendapat posisi sebagai isu yang akan ditindaklanjuti. Isu-isu tersebut masuk dalam agenda kebijakan melalui salah satu atau beberapa cara berikut ini:

a. Inisiatif dan prosesnya dilakukan oleh para pengambil kebijakan sendiri. Biasanya terjadi dalam proses pembuatan keputusan presiden, keputusan menteri dan sebagainya.

b. Desakan pihak lain di luar pemerintah, seperti (lembaga swadaya Masyarakat /LSM, organisasi massa, dan pertain politik). Dewasa ini, banyak kebijakan pemerintah dalam bidang ekonomi terpaksa dilakukan karena desakan dari IMF sekalipun di kalangan para ahli masih meragukan manfaatnya.

c. Lembaga-lembaga penelitian milik pemerintah melalui temuan-temuan ilmiah atau data-data yang di kumpulkan dalam masyarakat Hal ini banyak terjadi pada berbagai temuan BPPT dan LIPI.

d. Perorangan di luar organisasi pemerintah yang mengangkat suatu isu dalam masyarakat. contohnya, isu "busang" yang diangkat oleh "Amin Rais", sehingga berkembang menjadi langkah awal dari sebuah reformasi total.

e. Media massa yang mematangkan suatu isu, sehingga menjadi pusat perhatian pemerintah (Edward,et.al., $1978: 100$ ).

\section{Bentuk Pemerintahan Atau Realisasi Otonomi Daerah}

Dengan berbagai keterbatasan yang terdapat dalam proses penyusunan agenda dan formulasi kebijakan yang mengakibatkan tersingkirnya kepentingan kelompok yang lebih lemah dapat diatasi, jika rakyat diberi wewenang yang lebih langsung untuk ikut serta dalam proses tersebut. Keadaan ini berkaitan dengan struktur organisasi pemerintah dan distribusi wewenang yang lebih proposional dan komplementer pada setiap tingkat organisasi pemerintah itu, dengan kata lain, ini berarti perlakuan sistem otonomi daerah (Saputra dkk,2016) . 
Dalam sistem otonomi daerah, wilayah negara dibagi dalam unit-unit yang lebih kecil.masingmasing unit mempunyai wewenang untuk membuat kebijakan dalam batas yurisdiksi administrasinya sendiri. Dengan cara demikain, urusan pemereintahan didekatkan kepada rakyat, sehingga pemerintahan menjadi lebih efektif dan efisien. Menjadi lebih efektif karena penyelenggaraan pemerintahan yang berlangsung dalam wilayah yang lebih kecil, lebih memungkinkan penguasaan materi permasalahan dan penampungan aspirasi masyarakat dalam proses perumusan kebijakan.

Semakin dekat kepada rakyat, semakin dapat dihindarkan terjadinya perumusan dan pelaksanaan kebijakan yang sia-sia, karena rakyat secara langsung dapat mengawasi jalannya pemerintahan.lansung kepada rakyat sebagai pemilik negara. penyelenggaraan pemerintahan dalam unit yang lebih kecil dan lebih dekat kepada rakyat juga menjadi lebih efisien. Dalam proses perumusan kebijakan yang seperti itu, nilai-nilai yang hidup dalam masyarakat secara langsung dapat dilibatkan.

Waktu dan biaya yang diperlukan untuk di identifikasi aspirasi masyarakat dan sosialisasi rumusan kebijakan tersebut dapat ditekan sekecil mungkin.Dengan demikian, dapat ditumbuhkan kesdaran dan tanggung jawab rakyat terhadap penyelenggaraan pemerintahan.

Pemerintahan yang dekat dengan rakyat adalah pemerintahan yang realistis.Pengelolaan pemerintahan menjadi bagian dari kehidupan rakyat sehari-hari.

\section{Partisipasi Masyarakat}

Dalam proses penyelenggaraan pemerintahan, ada satu hal yang sangat penting, yaitu partispasi masyarakat. Partisipasi ini dapat mengambil bentuk dukungan dan/atau tantangan. Partisipasi ini boleh jadi bersifat spontan, berlanjut atau sporadis, secara damai atau kekerasan, legal atau illegal, efektif atau tidak efektif (hungtintong,et.al.,1990:4, (terj.)).

Hungtintong membatasi pengertian partisipasi sebagai "kegiatan warga Negara biasa (private citizen) yang bertujuan untuk memengaruhi pengambilan keputusan oleh pemerintah". Pengertian ini memiliki konotasi bahwa proses perumusan kebijakan dilakukan pemerintah "di luar rakyat". Rakyat berada diluar proses. Partisipasi rakyat hanya bersifat member pengaruh pada proses tersebut. Ditinjau dengan konsep pilihan sikap oleh pemerintah seperti yang telah disebutkan di atas, sikap pemerintah di sini bersifat aktif dan masyarakat sudah atau belum begitu berkembang.Hungtingtong juga melihat partisipasi sebagai kegiatan, bukan sekedar sebagai sikap dari orang-orang biasa, bukan oleh kalangan militer, birokrat atau para politisi professional.

Dalam perspektif ekonomi, seperti yang ditunjukan oleh Bryant dan white (1982), partisipasi dapat terjadi jika manfaat yang mungkin diperoleh lebih besar dari pada pengorbanan (biaya) langsung, maupun pengorbanan (biaya) tidak langsung. Suatu hal yang perlu dicatat adalah bahwa tidak dalam semua sistem pemerintahan, rakyat mempunyai kesempatan partisipasi yang sama besarnya dengan kesempatan untuk tidak berpastisipasi. Di Negara-Negara dengan sistem otoriter, rakyat tidak dapat mengelak untuk tidak melakukan partisipasi terhadap pelaksanaan kebijakan pemerintah, sekalipun mereka perumusan kebijakan.Dalam keadaan demikian, sesungguhnya kita tidak dapat menyebutnya lagi sebagai partisipasi, tetapi hanya mobilitasi.

\section{KESIMPULAN}

Agenda kebijakan tidak lain adalah sebuah daftar permasalahan atau isu yang mendapat perhatian serius karena berbagai sebab untuk ditindaklanjuti atau diproses pihak yang berwenang menjadi kebijakan. Badan Perpustakaan Dan Arsip (BPA) Kota Pekanbaru telah dengan baik melaksanakan agenda yang telah dibuat. Upaya lain yang dapat meningaktkan pelaksanaan agenda kebijakan publik adalah dukungan dana/ anggaran sesuai dengan yang diajukan. 


\section{SARAN}

Adapun faktor-faktor yang berpengaruh terhadap proses penyusunan agenda dan perlu ditingkatkan adalah dalam hal partispasi masyarakat dalam kebijakan publik. Masyarakat dapat mengambil bentuk dukungan dan atau tantangan. Partisipasi ini boleh jadi bersifat spontan, berlanjut atau sporadis, secara damai, legal, efektif atau tidak efektif. Peningkatan disiplin Pegawai Negeri Sipil dan Tenaga Harian Lepas (PNS dan THL) yang ada di Kantor BPA Kota Pekanbaru.

\section{DAFTAR PUSTAKA}

[1]. Abu Ahmadi dan Noor Salimi, 2008, Dasar-Dasar Pendidikan Agama Islam, Bumi Aksara, Jakarta.

[2]. Agus Dkk, 2012, Modul Monitoring Penegakan Hukum, ICW, Jakarta.

[3]. Anggara Sahya. 2012. Perbandingan Administrasi Negara. CV Pustaka Setia, Bandung.

[4]. Beddy Iriawan, 2012.Sistem Politik Indonesia, Rajawali Pers, Jakarta

[5]. Danang Sunyoto dan Burhanuddin, 2011, Perilaku Organisasional, CAPS, Yogyakarta.

[6]. Deddy Mulyadi, 2015. Studi Kebijakan Publik Dan Pelayanan Publik, Alfabeta, Bandung.

[7]. Kaelan, 2010, Pendidikan Pancasila, Paradigma, Yogyakarta.

[8]. MPR RI, 2012, Ketetapan MPR RI Nomor I/ MPR/ 2003 Tentang Peninjauan Kembali Materi dan Status Hukum Ketetapan MPR Sementara dan Ketetapan MPR RI Tahun 1960 -2002, Sekretariat Jenderal MPR RI, Jakarta

[9]. Padmo Wahjono dan Nazaruddin Syamsuddin, 2009, Pengantar Ilmu Politik, PT Raja Grafindo Persada, Jakarta.

[10]. Riant Nugroho dan Randy Wrihatnolo, 2011, Manajemen Perencanaan Pembangunan, Kompas Gramedia, Jakarta.

[11]. Ridwan HR, 2010, Hukum Administrasi Negara, PT Raja Grafindo Persada, Jakarta.Said Zainal Abidin, 2012, Kebijakan Publik, Salemba Humanika, Jakarta.

[12]. Saputra, T., \& Marlinda, P. (2017). Capaian Pelayanan Kesehatan Dasar Di Kota Pekanbaru. Jurnal Ilmu Sosial Mamangan, 5(2), 79-88.

[13]. Siti Fajar dan Tri Heru, 2013, Manajemen Sumber Daya Manusia, UPP STIM YKPN, Yogyakarta.

[14]. Subhan Sofhian dan Asep Sahid, 2011, Pendidikan Kewarganegaraan, Fokus Media, Bandung.

[15]. Wibowo, 2010, Budaya Organisasi, Rajawali Pres, Jakarta. 
[16]. Yusuf Muri, 2014, Metode Penelitian; Kuantitatif Kualitatif dan Penelitian Gabungan, Prenada Media Grup, Jakarta. 